\title{
A la MeSA DEL TIRANO: Poder Y \\ GASTRONOMÍA EN LA NOVELA DE LA DICTADURA \\ Milagros Santiago Hernández*
}

\author{
Editorial Petricor, San Juan, Puerto \\ Rico, 2019, 272 P.
}

Ernesto Mächler Tobar ${ }^{1}$

\footnotetext{
* Cómo citar esta reseña: Mächler Tobar, E. (2021). Reseña del libro A la mesa del tirano: Poder y gastronomía en la novela de la dictadura de Milagros Santiago Hernández. Estudios de Literatura Colombiana 49, pp. 263-268. DOI: https://doi.org/10.17533/udea.elc.n49a15

1 https://orcid.org/0000-0001-8978-3862 ernesto.machler@u-picardie.fr Université de Picardie Jules Verne, CEHACentre d'Études Hispaniques d'Amiens, France.
}

Editores: Andrés Vergara Aguirre, Christian Benavides Martínez

Recibido: 23.05 .2021

Aprobado: 21.05.2021

Publicado: 30.06 .2021

Copyright: $@ 2021$ Estudios de Literatura Colombiana. Este es un artículo de acceso abierto distribuido bajo los términos de la Licencia Creative Commons Atribución No comercial - Compartir igual 4.0 Internacional

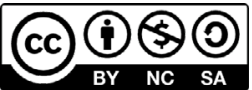

El ensayo se abre con el poema de José Martí, "Banquete de tiranos": déspotas glotones se alimentan de hombres y de almas a la vez que perfuman sus dientes. Aquí todos somos el plato fuerte en el juego sangriento de los dictadores. Los sátrapas conforman una de las plagas que con frecuencia han marcado la historia de América Latina, abusando de su poder absoluto y arbitrario. Desde la Independencia, cada país ha conocido uno o varios gobernantes de este tipo, llámense dictadores, tiranos, arbitrarios, teósofos, sanguinarios o nepotistas, seres a menudo cercanos a la locura. Algunas veces asociados a la cúpula militar, y no exentos de carisma, los dictadores se convierten en personaje recurrente en nuestra literatura, que ficcionaliza sus historias, sean reales o inspiradas por diversas encarnaciones. La temática de la dictadura en la literatura ya ha sido abordada por muchos ensayistas, y es imposible olvidar los ejemplos de Ángel Rama, Los dictadores latinoamericanos (1976), de Conrado Zuluaga, Novelas del dictador, dictadores de novela (1977), y 
de Adriana Sandoval, Los dictadores y la dictadura en la novela hispanoamericana, 1851-1978 (1989), entre tantos otros.

La novedosa y osada propuesta de la investigadora boricua Milagros Santiago Hernández es concebir la dictadura como un abyecto suceso antropofágico. Se sirve con audacia de este ángulo de visión para abordar la ficcionalización de la dictadura latinoamericana, encarnada básicamente en tres novelas: La carne de René (1952) de Virgilio Piñera, Yo el Supremo (1974) de Augusto Roa Bastos y El otoño del patriarca (1975) de Gabriel García Márquez, que ocupará prioritariamente nuestra atención. Las referencias gastronómicas son interpretadas como patentes metáforas del autoritarismo. ¿Es válida esta lectura como marco teórico? Como recurso de análisis literario, la gastrocrítica (palabra creada por Ronald Tobin) ha sido escasamente empleada, si bien autores como Rita de Maeseneer se han lucido con ella, como en Devorando a lo cubano. Una lectura gastrocritica de textos relacionados con el siglo XIX y el Periodo Especial (2012), por ejemplo. El presente ensayo de Milagros Santiago ha sido merecedor del premio PEN Club Puerto Rico Internacional, categoría Ensayo 2020. El jurado destaca su "mirada diferente y refrescante". Habría que añadir que su visión viene también impregnada de humor negro y de originalidad, a la vez que respira con una libertad de carnaval, como se aprecia particularmente en los incisivos epígrafes de los apartados.

El libro está dividido en cinco capítulos que incitan la salivación. Milagros Santiago cimenta la base de su análisis gastrocrítico: "De esta forma, lo que comen o dejan de comer, el modo y la frecuencia con que se ingieren los alimentos, los cambios en los hábitos alimentarios y de sobremesa [...] determinan muchas veces la evolución de los actantes y los giros de la trama" (p. 10). Afirma que todo ello son fundamentos estructurantes del discurso político. En "Dictadores en su tinta”, evoca aquellos tiranos literarios que justifican tallar en mármol la frase de George Orwell: "El poder no es un medio, es un fin". Su panorama cronológico del bosque destaca árboles como en las novelas de Esteban Echeverría, "la primera gran metáfora gastronómica” (p. 14), José Mármol, Ramón del Valle-Inclán, Miguel Ángel Asturias, Alejo Carpentier, Mario Vargas Llosa, Enrique Lafourcade y Zoé Valdés. Los hábitos alimentarios opíparos o parcos, el dominio de la etiqueta y de la sobremesa, por lo general desconocido por los dictadores, son claramente maneras de hacer patente el control social al evidenciar la diferencia entre la 'civilización' y la 'barbarie'. Por ello, destaca "la práctica de los ágapes como herramienta para manipular la opinión 
pública” (p. 37). La imposta puede ser simbólica, como en el acto sexual: el coito sería un "alimento subversivo y acto de evasión en tiempos de hambre" (p. 40) y, como en la novela de Valdés La nada cotidiana (1995), un evidente acto de protesta. El papel cómplice de la Iglesia, en especial de los jesuitas, adquiere contundencia al disfrazar al tirano como protegido de Dios. Igualmente cómplices son la oligarquía, los ricos industriales y hacendados, el ejército y, de manera abierta o camuflada, los intereses de los Estados Unidos. A veces, en su pasión devoradora, Santiago impone el argumento gastronómico, restándole penetración al desarrollo analítico, pero sus observaciones nunca dejan de ser pertinentes.

"Ingredientes para cocinar una dictadura" aborda el control del hambre para manipular la población; el viejo Panem et circenses que, como una cornucopia de la abundancia, tiene por objetivo impedir a la gente el reunirse para complotar. Sirviéndose del léxico de la gastronomía como lenguaje común que todos entienden, el discurso político del tirano y sus bandos de información crean un aglutinante que lo identifica con el pueblo y lo hace parte de su carisma: "Dicho cariz mítico reside, entre otros factores, en el poder que le otorga al dictador su filiación con las masas populares" (p. 49). El cuerpo del déspota en El otoño del patriarca es creado con fragmentos de varios de los innumerables dictadores que ha conocido el continente, una suerte de Frankenstein que tetaniza la atención, primero por la violencia y la abyección, luego por su caducidad, pues termina como carne para gallinazos. El tiempo en esta novela es similarmente un vientre que devora y digiere a sus víctimas. La descomposición de muchas dictaduras ficcionales viene justamente de la 'mortecina' o cadaverina que corrompe a los aliados del poder, ahítos de las prebendas que van obteniendo a la sombra del tirano: "El hambre de poder es una enfermedad altamente contagiosa, sobre todo tratándose de personas tan cercanas a la cabeza del gobierno”, sostiene Santiago (p. 99).

El Patriarca ignora el correcto protocolo del buen comer, es una fuerza bruta que se manifiesta animalizada y que despliega un populismo a ultranza. Si Leticia Nazareno es la guía de tan complejo aprendizaje, permite meditar que "la pérdida del dominio dictatorial aparece asociada al refinamiento de sus hábitos de comensal” (p. 52). ¿Apacigua la civilización al bárbaro? En la novela de Roa Bastos el dictador es autofágico, una suerte de divinidad que nutriéndose de sí misma fortalece el poder, una teogonía de fénix que garantiza la perpetuidad del régimen, una automutilación regenerativa próxima a la ceremonia eucarística. Por el contrario, en Piñera ese ente es una fuerza 
diluida e integrada al cuerpo social, poseedora de la mirada panóptica de vigilancia perfecta. Una censura bien empleada, por su mismo carácter represivo, termina por generar una autocensura propia a la víctima, como se evidencia en los Comités de Defensa de la Revolución. El carácter individual del ciudadano desaparece trocado en un colectivo de masa autorregulada. El régimen autoritario instiga para que la población pelee por un subterfugio que se ha vendido como esencial, de modo que no se rebele por la vital libertad. Nace "El espectáculo del hombre a quien ciega el poder para poder devorarlo mejor", en palabras de Rama.

“Gastronomía y patriarcado” ilustra cómo el pueblo obedece cuando la opresión va acompañada del hambre. La metáfora ideal será el acceso al consumo de carne. Muchos dictadores son estancieros feudales, y las vacas que se desperdigan representan la lenta desintegración del poder. García Márquez mitologiza las dimensiones extraordinarias del patriarca en la percepción de la mano enguantada por la mente colectiva: "bastaba con que él señalara con el dedo a los árboles que debían dar frutos y a los animales que debían crecer y a los hombres que debían prosperar". La mano como ente creador y ordenador del universo. Carne, leche, miel, amaranto, maíz, sal, son alimentos vitales de los que se sirven las dictaduras para manipular al pueblo. La sal es utilizada por el patriarca para combatir el brote de fiebre amarilla, como si otorgara al mismo tiempo incorruptibilidad a la dictadura. Pero, como escribe Tomás Val, citado por Santiago, "El poder es como esos nuevos alimentos envasados: también tiene fecha de caducidad" (p. 151).

“Con la sartén por el mango" se ocupa de las mujeres que utilizan los fogones de la cocina "como una trinchera de contraataque" (p. 159), representando la enorme influencia de las madres, esposas o amantes latinoamericanas, que a veces son encarnaciones más tiránicas y déspotas que el mismo cónyuge. Tal es el caso de Leticia Nazareno, solapada y usurpadora, vago reflejo de la madre del patriarca: ella sabe que, como lo afirma la creencia popular, el hombre se conquista por el estómago. Por cierto, Bendición Alvarado se descompone en una suerte de espejo de la putrefacción del régimen. Las demás mujeres en El otoño del patriarca son apenas concubinas reales o posibles, sumisas o violadas, a las que tomar por asalto, sin tomarse el trabajo de la desnudez, asaltos que son imágenes de la rusticidad de los dictadores, "antítesis de los gobiernos ilustrados y democráticos” (187). Mujeres que parecen no percibir la agresión sexual (¿es ello posible?), pero que emplean esta forma de resistencia pasiva 
para desmoralizar al dictador y castrarlo metafóricamente. Por ello termina baboso, viviendo amoríos de adolescente con niñas de trece años que le revitalizan el grotesco cuerpo. El ansiado aliento de regaliz de Manuela Sánchez es ansia de juventud imperecedera e incorruptible, pero afrodisíaca.

"Banquete carroñero" analiza cómo se implanta en la memoria colectiva el personaje del dictador, en especial por medio de la mistificación póstuma. En la novela de Piñera, después de la ceremonia de lamer el cadáver de René, el cuerpo es cremado, lo que cancela la posibilidad de un retorno; se deshace aquí el cuerpo social de la población cubana, no el del tirano. E1 Supremo de Roa Bastos presume que "Condenado a vivir en el corazón de una raza, también estoy atado al naranjo de las ejecuciones”, y se siente así signado por la inmortalidad. El patriarca, devorado por los buitres, adquiere la posibilidad de ascender en vuelo circular y de dominar el espacio. Las ceremonias de homenaje preludian la llegada de una nueva época; no obstante, los cuerpos déspotas consumidos por gusanos o buitres son apenas la instauración de una nueva tiranía, lo que se hace ya patente en el cuento "Los funerales de la Mamá Grande” (1962) del Nobel colombiano. Al servir a la mesa el cadáver de su hombre de confianza, Rodrigo de Aguilar, el patriarca no solo se venga sino que genera la aglutinación cómplice de los convocados al banquete: "La unión de un cuerpo militar fragmentado a través del desmembramiento y la ingesta del ente disociativo", escribe Santiago (p. 245). Recuérdese no solamente el Titus Andronicus (1594) de Shakespeare, sino la película de Peter Greenaway, The Cook, the Thief, his Wife and her Lover (1989).

A la mesa del tirano nos presenta la figura del dictador y el aparato de poder que le rodea como una bestia voraz que se nutre de la patria hambreada y digiere inmisericorde a todo detractor, pero finalmente debe conceder que sus propios despojos sirvan de nutrimento a carroñeros. Sin embargo, dicha muerte no representa el final del convite, como lo plantea Santiago, sino su entrada al mito y la apertura del camino a la sucesión. "La escritura salva a los tiranos del olvido al sacarlos del tintero en que se ahogan", afirma (p. 219). La novela de la dictadura ha conocido varias etapas, iniciando como denuncia del horror para pasar a constituir un fácil reclamo panfletario, y evolucionar finalmente hacia la construcción de una metáfora del poder omnímodo; pero los dictadores están lejos de dejar de ser una significativa atracción ficcional. Ismail Kadaré sostiene que "La dictadura y la literatura no pueden ser concebidas sino como dos fieras que se atrapan permanentemente por el cuello, y de este combate es el escritor quien 
sale vencedor, puesto que las heridas que él inflige tienen manifestaciones tardías que no cicatrizan nunca". Mientras que algunas plumas, en momentos de deshonrosa carencia de discernimiento, ensalzan a los dictadores y comen a su mesa, como José Antonio Osorio Lizarazo en su hagiográfica Asi es Trujillo (1958), otras, afortunadamente la lúcida mayoría, cantan con Jorge Zalamea (1952) sin cansancio: "El mundo todo ya no era de sangre sino de agua chirle, como el Gran Burundú-Burundá no era otra cosa ya que un obeso papagayo de papel”. Si el dictador y su ficcionalización son perennes, que también lo sea nuestra denuncia. "Los dictadores terminan siendo devorados por su propia hambre de poder” (p. 252), concluye la ensayista Milagros Santiago. Pasemos a manteles, ipero nadie debe comer con la boca cerrada! 